\title{
PERENCANAAN LINE BALANCING GUNA MENINGKATKAN OUTPUT PRODUKSI
}

\author{
Teguh Baroto ${ }^{1}$
}

\begin{abstract}
Every company will always have main goal in a maximum bennefit. For this, one factor which support this is how to make a good production process. This will be reached if balancing line of production floor has average stressing of work especially for assembly company because material handling in a work station will influence another work station and cause production target of company won't be available.

For getting line balancing use Rank Positional Weighat (RPW), method which is a heuristic methods that is statement of trial and error approaching. This method depends on the function value for each work operation based on the standard time for each work activities following the production process ranking (presedence diagram).

From the analysis using RPW method can be found optimum balance delay to each type of ARM product is from $60,46 \%$ to $20,5488 \%$ with production output from 113,50 units/day become 116 unit/day, and also work efficiency from $60,50 \%$ to $78,4511 \%$, with workstation number about 7 work stations. In other hand for type of BED product 15 has balance delay from $35,29 \%$ to 16,454 with production output increase from 77,44 unit/day become 120 unit/day and also has efficiency about $64,71 \%$ become $83,548 \%$ with work station number about 6 . Then it can be concluded that work station design using RPW method will increase output product especially for assembly company.
\end{abstract}

Key Words : Line Balancing, RPW, Precedence Diagram.

\section{PENDAHULUAN}

Dalam menghadapi pasar global ,seperti sekarang ini yang didukung perkembangan IPTEK yang sangat pesat menuntut dunia perindustrian untuk untuk mengadakan perubahan-perubahan sistem yang ada di dalamnya.

Masalah keseimbangan lintasan dalam aliran proses produksi untuk saat ini msih sering diabaikan dalam suatu industri. Padahal dalam kenyataannya output / target produksi dan produktifitas kerja sangat sangat dipengaruhi oleh adanya lintasan produksi yang sistematis. Pengaturan lintasan produksi yang salah akan berakibat pada tingginya waktu dan biaya produksi serta tidak efektifnya penggunaan tenaga kerja.

Ketidak seimbangan lintasan produksi ini dapat dilihat dari adanya gejala mengganggur pada beberapa pekerja / mesin, juga adanya penumpukan barang setengah jadi di lantai produksi antara mesin satu dengan mesin yang lain, hal ini disebabkan oleh adanya perbedaan kapaditas produksi dan ketidakseimbangan waktu operasi dari lintasan tersebut.

Terutama untuk perusahaan manufaktur / perakitan masalah lintasan 
keseimbangan ini akan berpengaruh sekali terhadap pencapaian output produksi. Hal ini disebabkan oleh adanya keterkaitan antara stasiun kerja satu dengan stasiun kerja yang lainnya. Dengan adanya fenomena tersebut maka sangatlah penting untuk dibuat satu perencanaan lintasan keseimbangan yang lebih sistematis dengan keseimbangan yang paling minimal dengan biaya yang minimal pula.

\section{Keseimbangan lintasan produksi (Line Balancing)}

Kriteria umum keseimbangn lintasan produksi adalah memaksimumkan efisiensi atau meminimumkan balance delay, dan tujuan pokok dari penggunaan metode ini adalah untuk mengurangi atau meminimumkan waktu menganggur (idle time) pada lintasan.

Tujuan perencanaan keseimbangn lintasan adalah mendistribusikan unit-unit kerja atau elemen-elemen kerja pada setiap stasiun kerja agar waktu mengganggur dari suatu lintasan produksi dapat ditekan seminimal mungkin sehingga pemanfaatan peralatan dan operator dapat digunakan semaksimal mungkin.

Untuk menyeimbangkan lintasan produksi secara garis besar metode yang ada terbagi atas 2 bagian yaitu :

1. Metode Analitis

Merupakan metode dengan pendekatan sistematis yang memberikan solusi yang optimal tetapi memerlukan perhitungan yang besar dan rumit.

2. Metose Heuristik
Metode ini menyatakan pendekatan "trial and error" dan teknik ini memberikan hasil yang secara matematis mungkin tidak optimal, tetapi secara praktis memberikan hasil yang memuaskan.

\section{Metode Rank Positional Weight}

Metode Rank Positional Weight juga bisa disebut dengan metode Helgeson Birnie dimana metode ini merupakan salah satu metode heuristik yang ada. Metode Rank Positional Weight pada suatu operasi bisa dinyatakan dengan jumlah waktu dari suatu operasi yang dicari bobot posisinya ditambah dengan semua waktu dari operasioperasi yang mengikutinya pada "Precedence Diagram".

Langkah-langkah metode Rank Positional Weight adalah :

1. Buat Precedence Diagram

2. Menghitung bobot posisi masingmasing operasi kerja

3. Membuat urutan masing-masing operasi berdasrkan bobot posisinya. Urutan pertama dengan bobot posisi terbesar dan yang terakhir adalah yang paling kecil. Jika ditemui dua elemen atau lebih mempunyai bobot yang sama, bisa diurutkan sesuai urutan operasinya.

4. Menetapkan waktu siklus operasi berdasarkan output yang telah ditetapkan.

5. Menempatkan operasi-operasi dalam stasiun kerja dengan cara menempatkan operasi atau elemen 
kerja dengan bobot posisi terbesar pada stasiun kerja pertama, kemudian berikutnya dengan batasan waktu tiap stasiun kerja tidak boleh melebihi waktu siklus dan penggabungan elemen kerja menjadi satu stasiun kerja tidak boleh dipaksakan.

6. Ulangi step ke-5 sampai semua elemen kerja ditempatkan.

\section{Precedence Diagram}

Precedence diagram merupakan gambaran secara grafis dari urutan operasi kerja, serta ketergantungan pada operasi kerja yang lainnya dengan tujuan untuk memudahkan pengontrolan dan perencanaan kegiatan yang terkait di dalamnya.

\section{Waktu Siklus Stasiun Kerja}

Waktu siklus adalah waktu yang diperlukan oleh lintasan produksi untuk menghasilkan satu unit produk. Untuk merencanakan kesimbangan lintasan produksi maka sejumlah produksi tertentu waktu siklusnya harus sama atau lebih besar dari waktu operasi terbesar yang menjadi penyebab terjadinya bottle neck (kemacetan) dan waktu siklusnya juga harus sama atau lebih kecil dari jam kerja efektif perhari dibagi dari jumlah produksi perhari, secara matematis dapat dinyatakan sebagai berikut :

$$
t i{ }_{\text {max }} \leq C \leq \frac{P}{Q}
$$

Dimana :

Ti max

Waktu operasi terbesar

$\mathrm{C}$

: Waktu Siklus

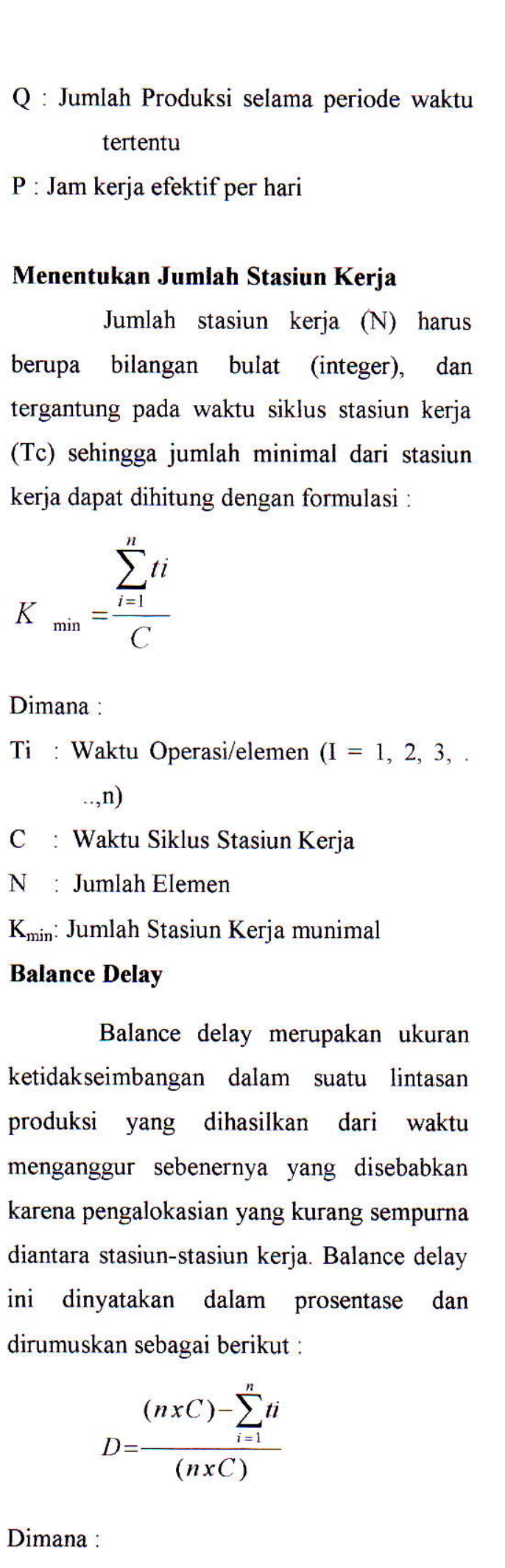

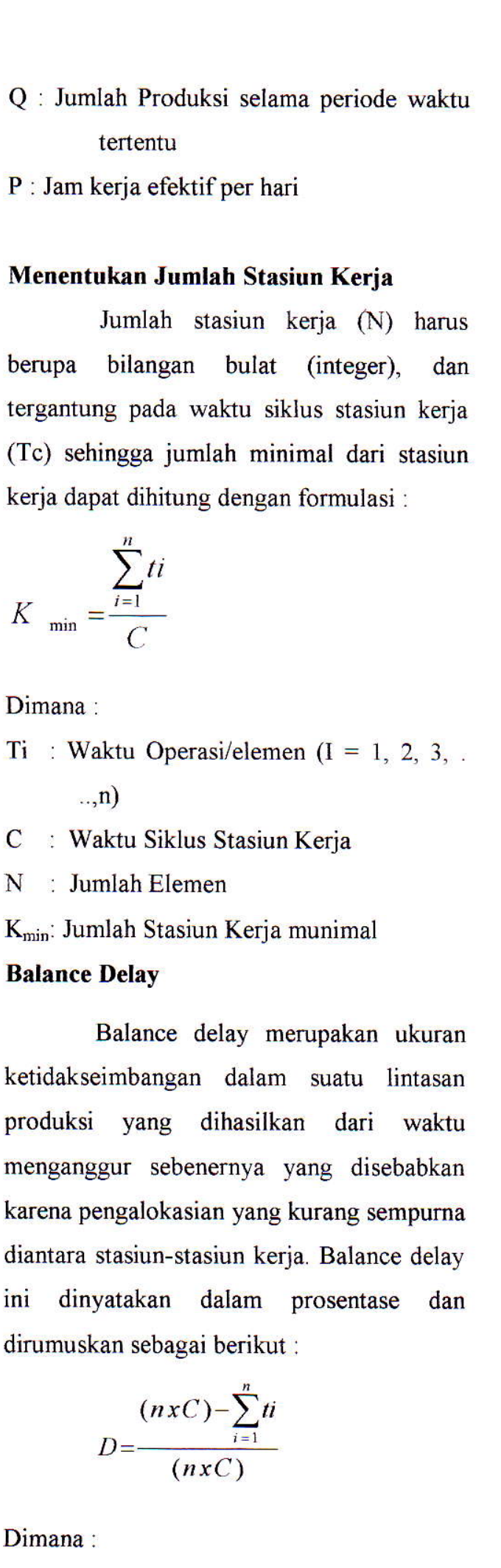

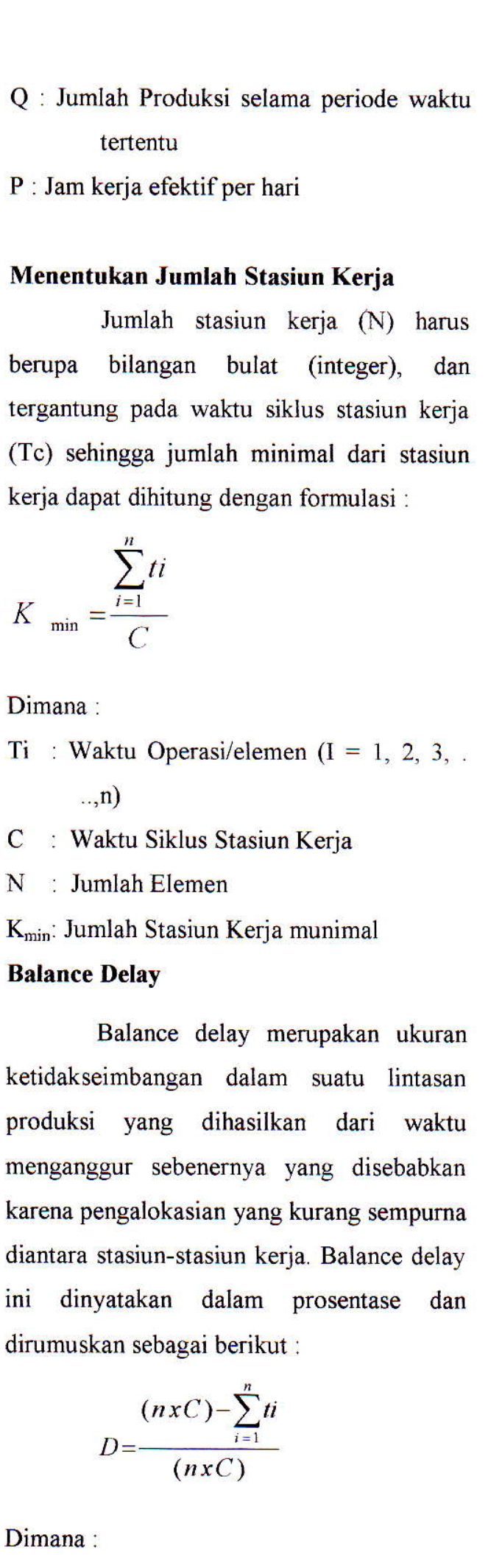

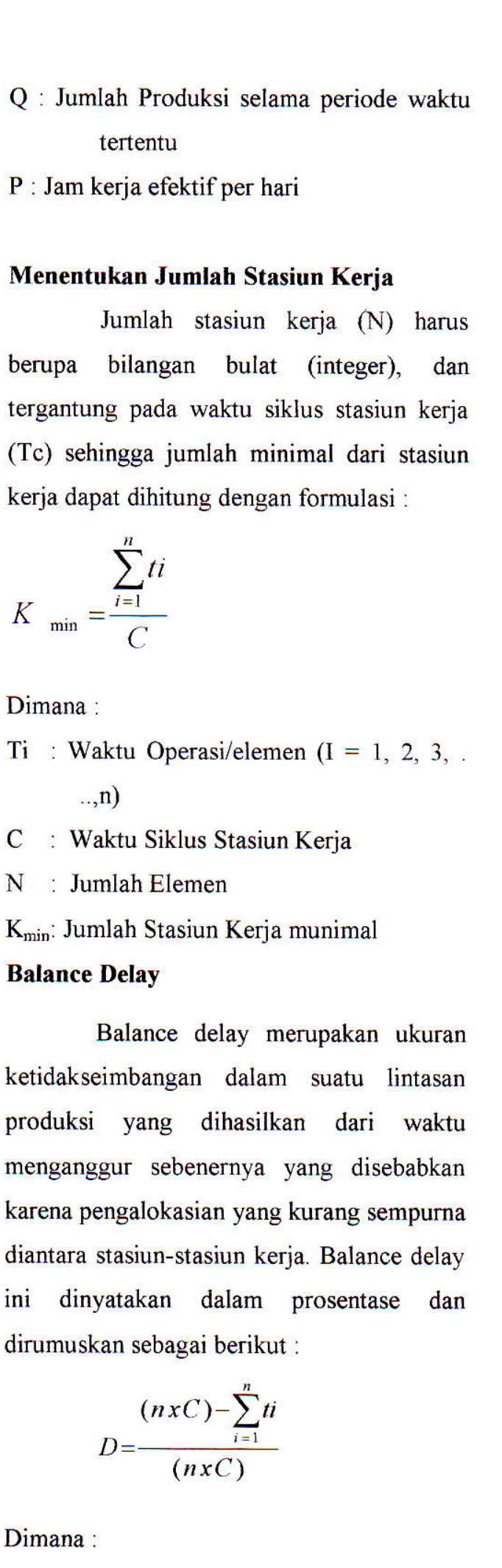

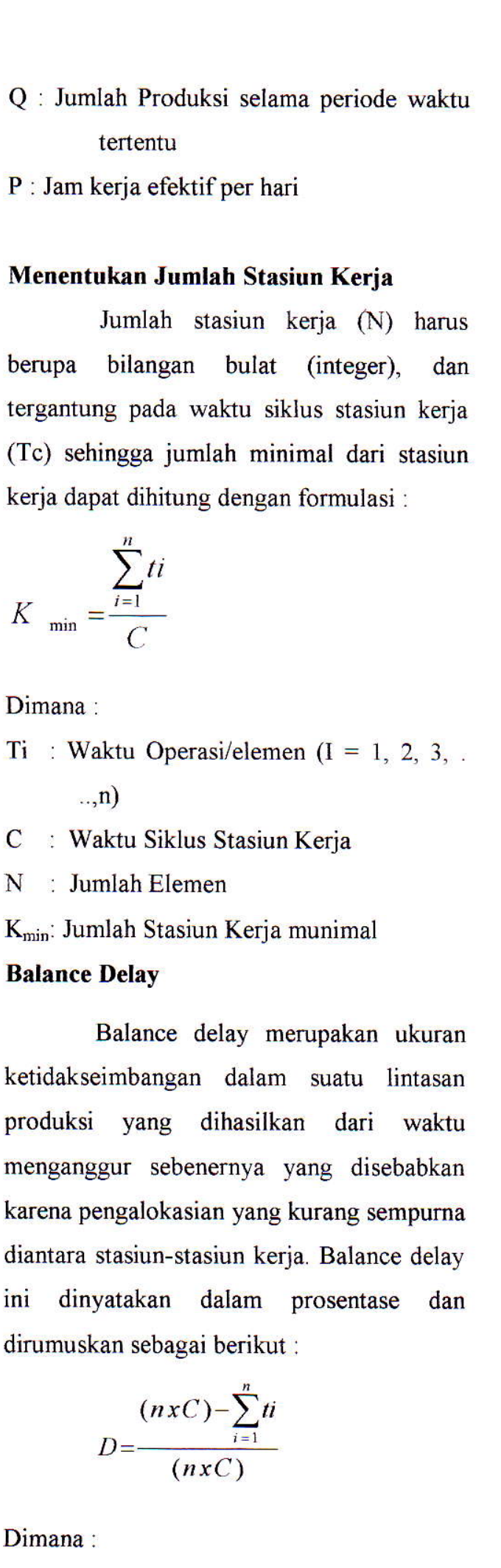

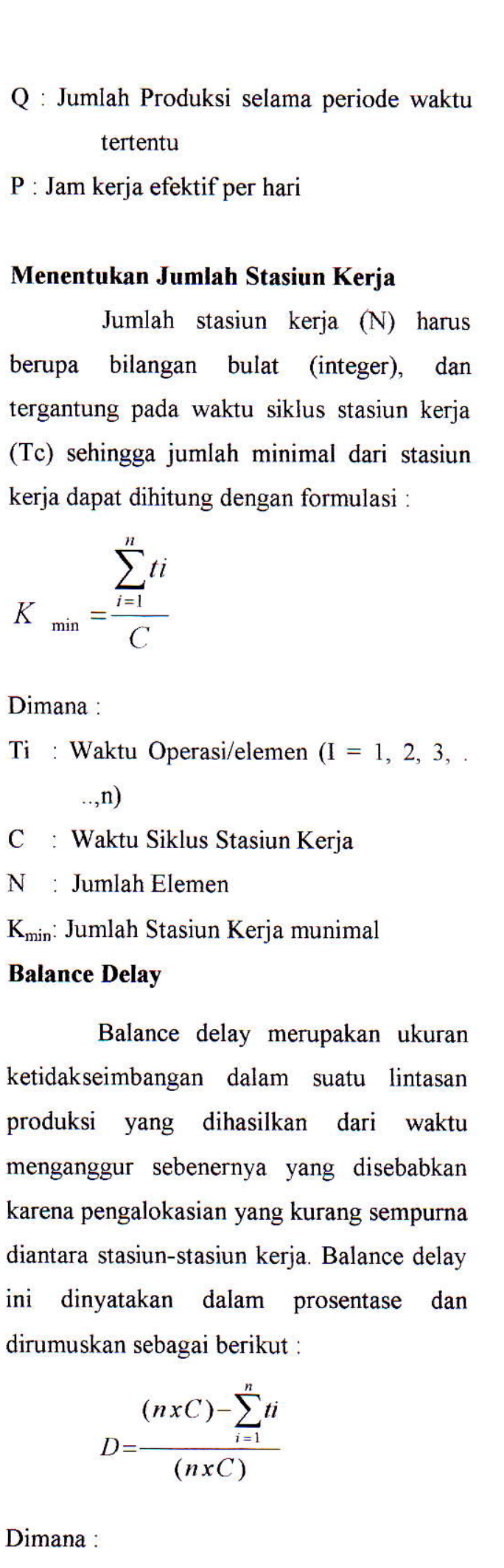

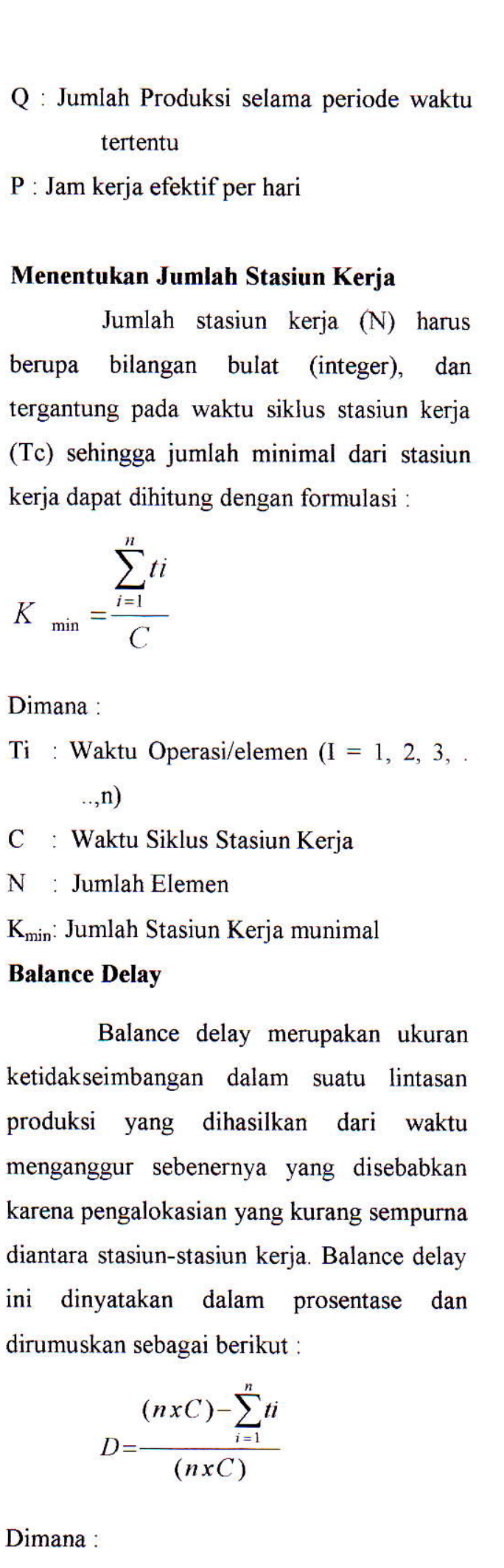

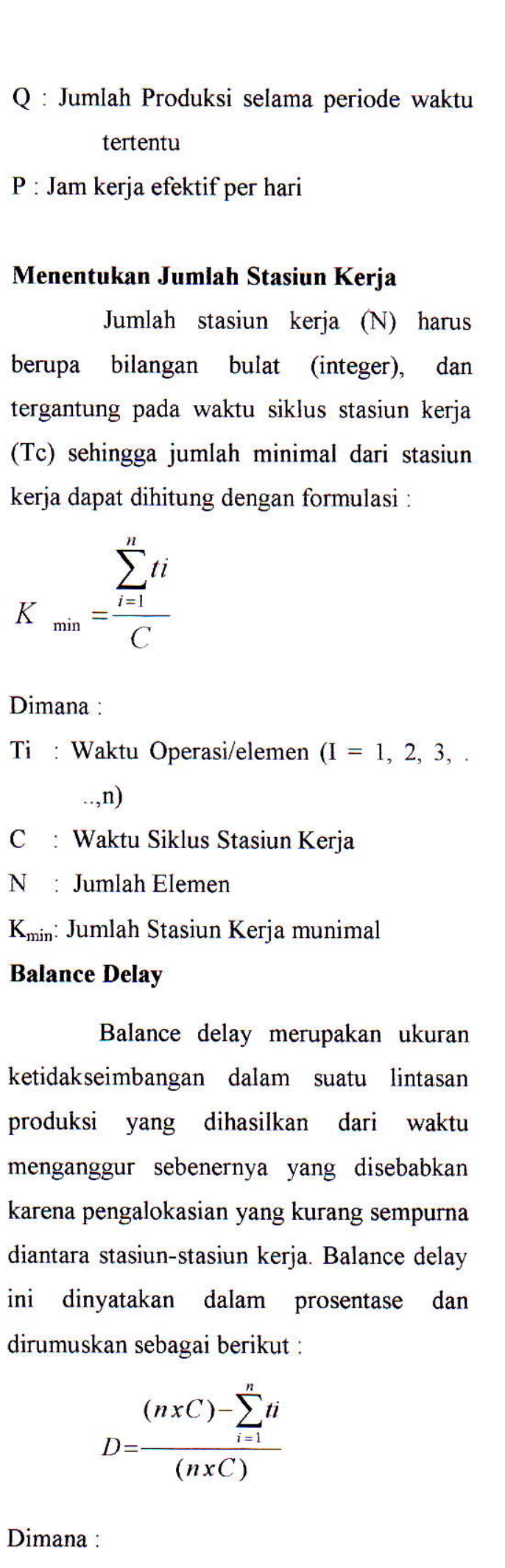

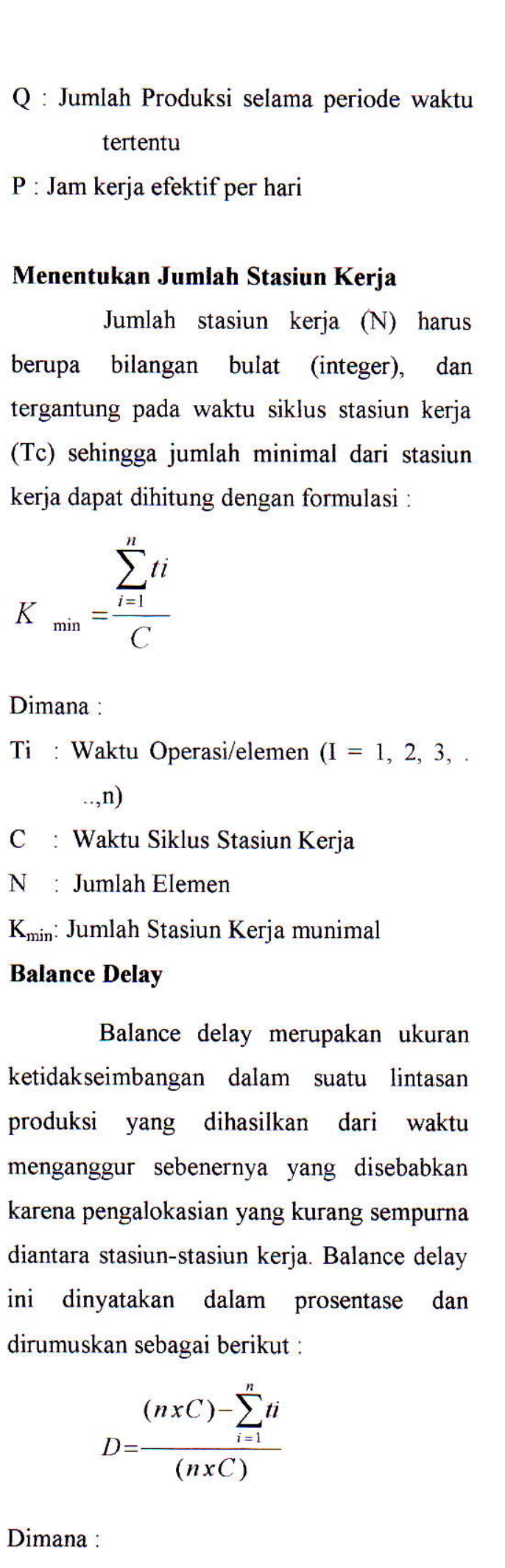

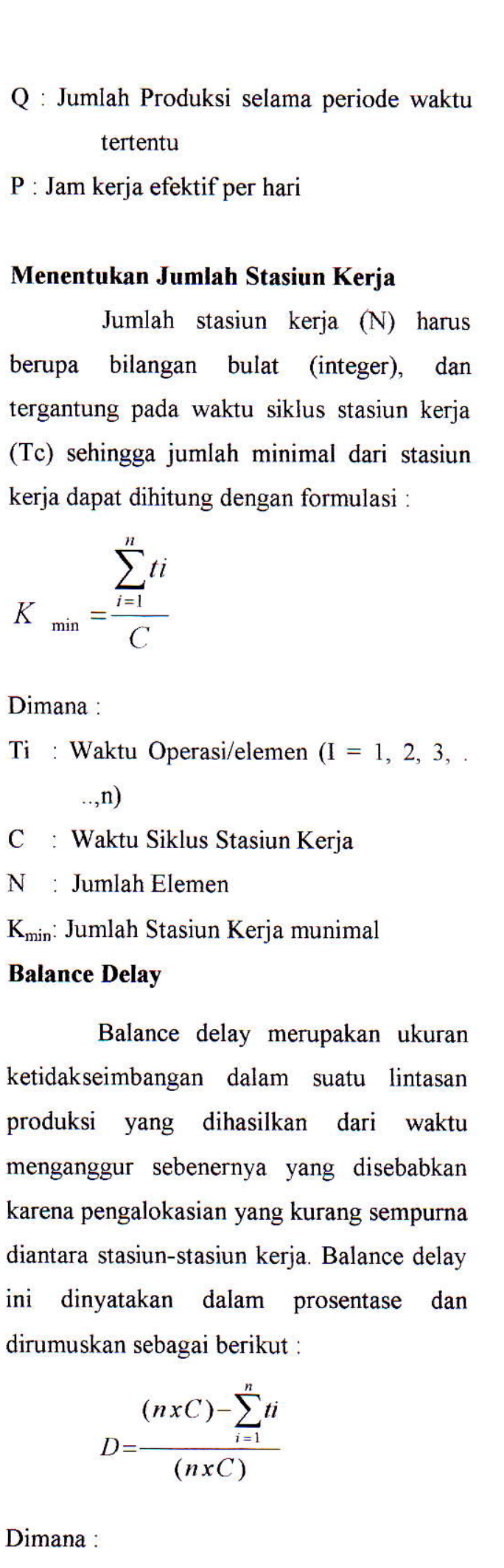

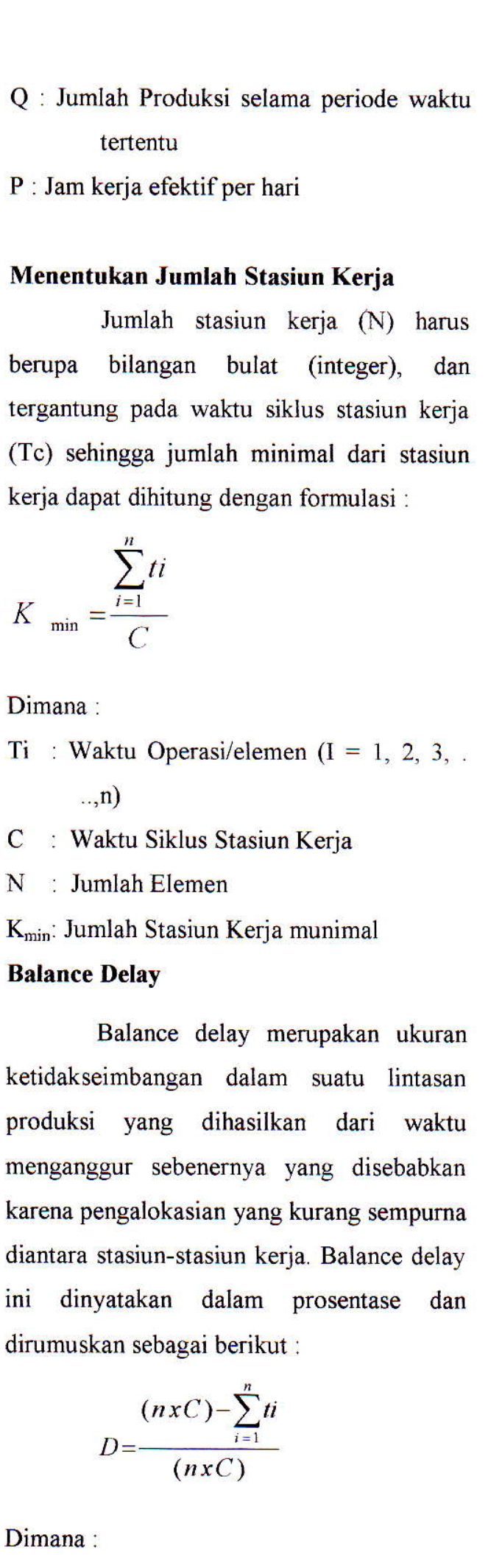

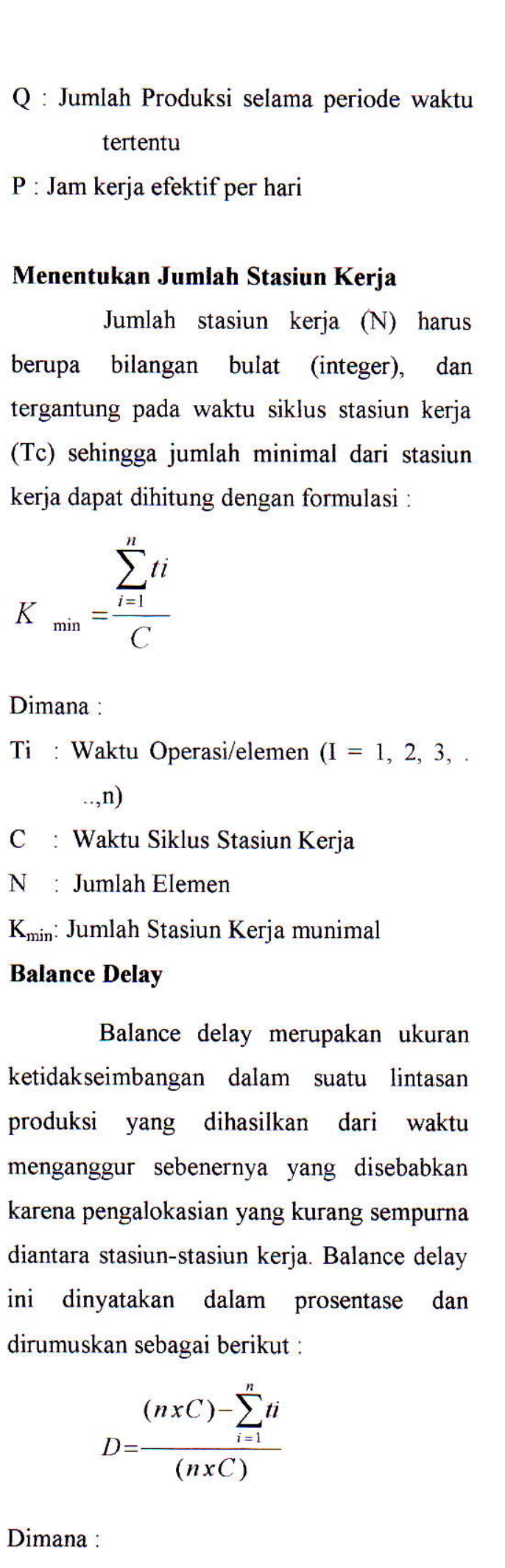

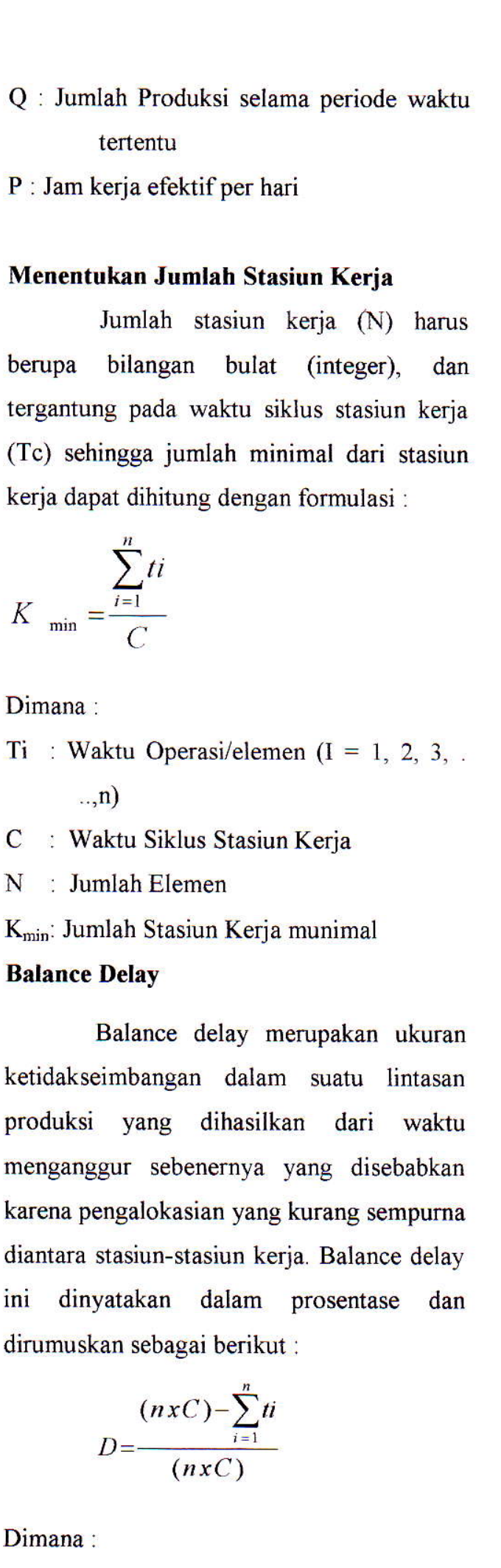

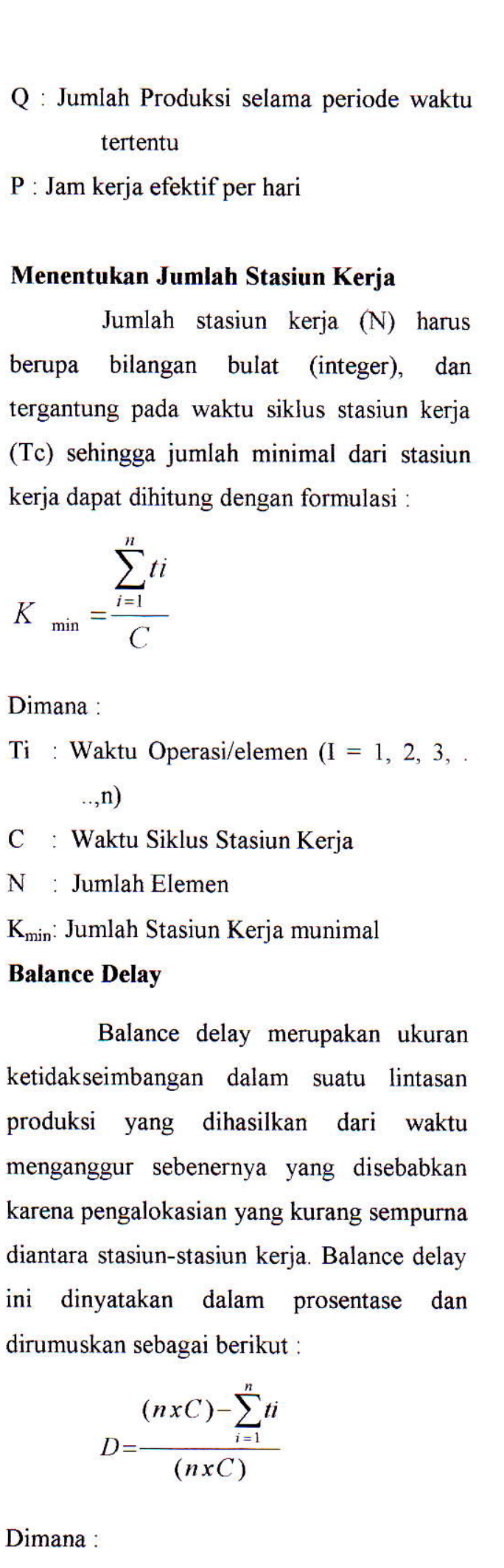

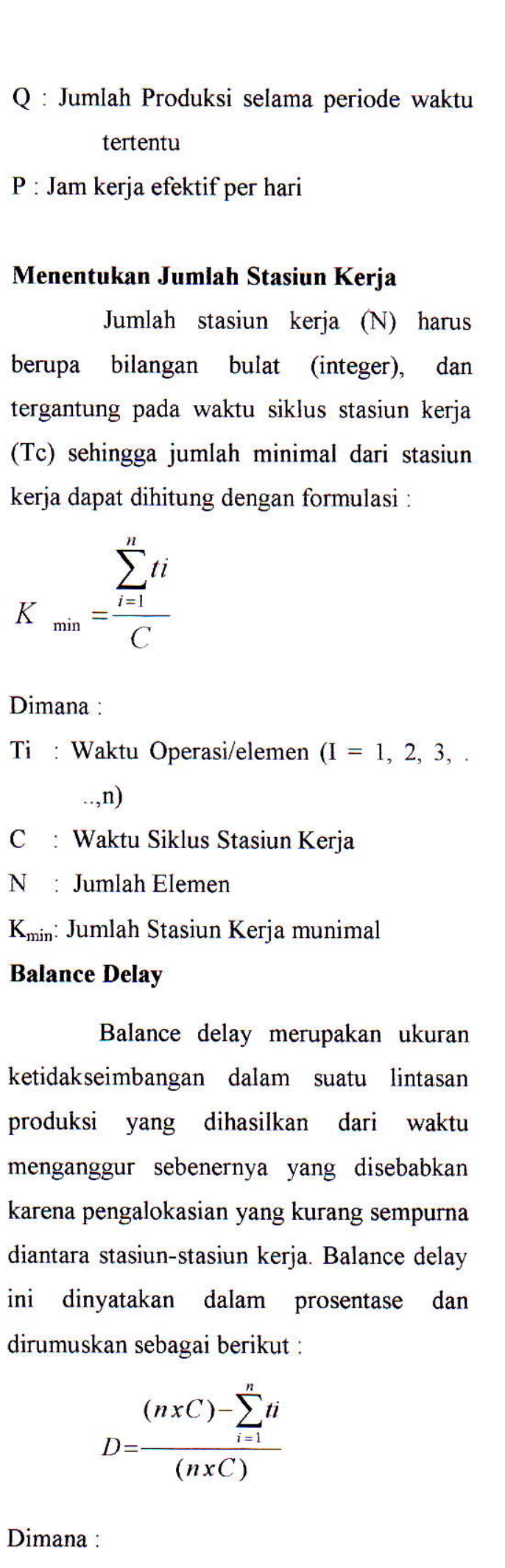

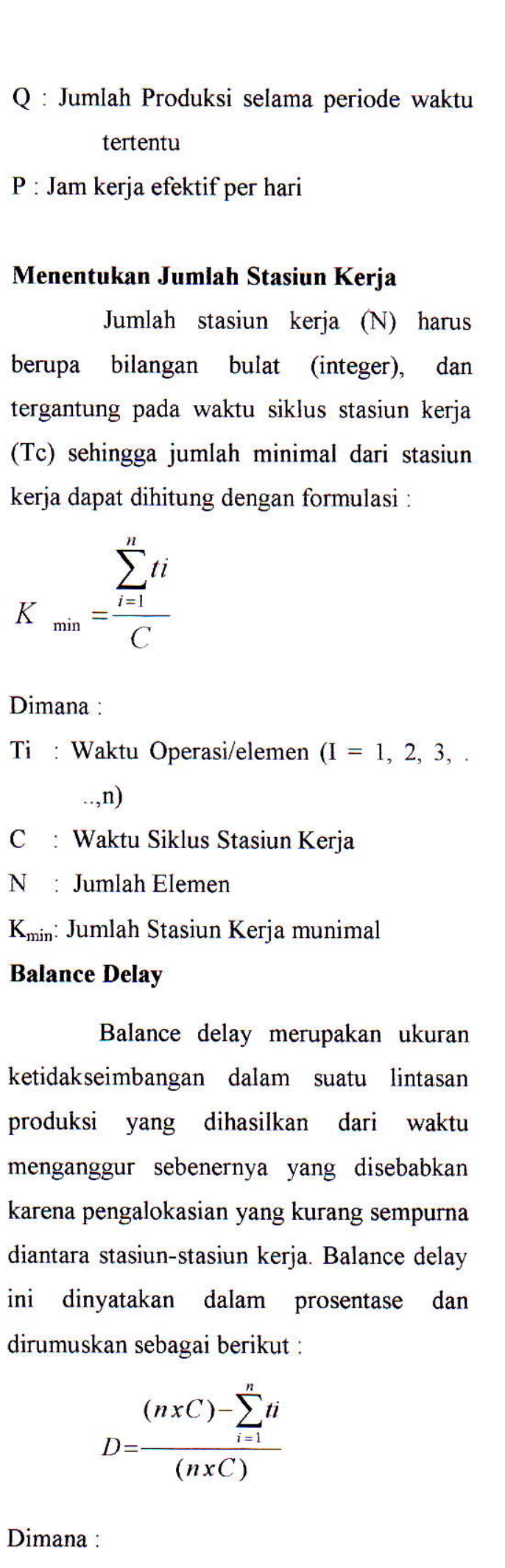

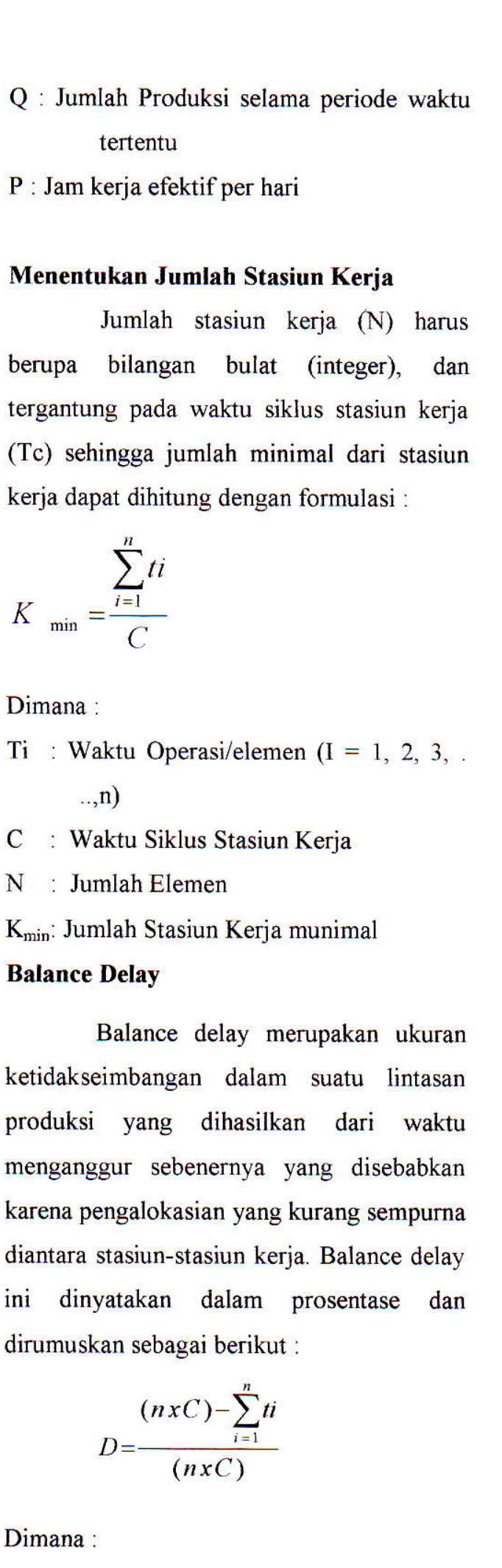

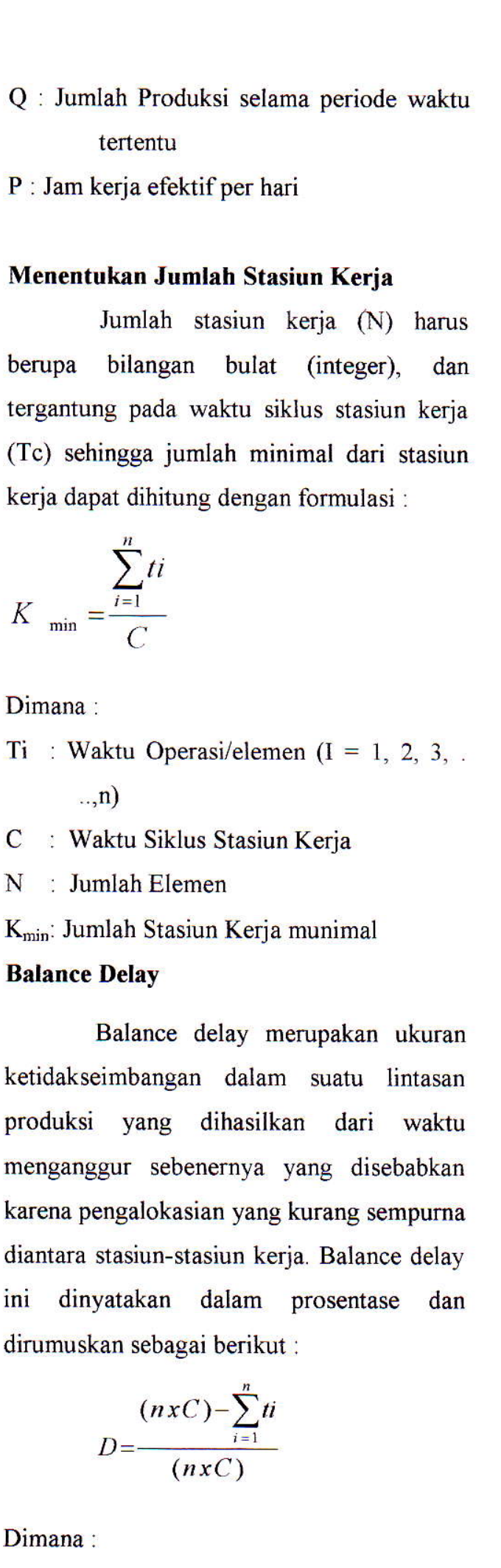

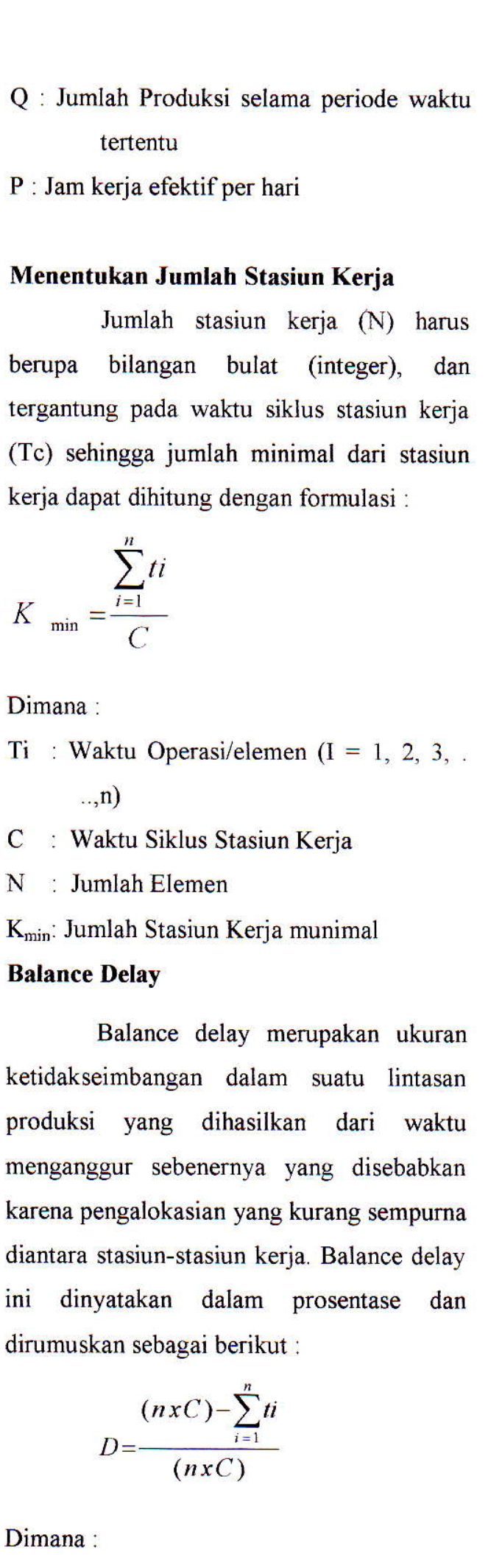

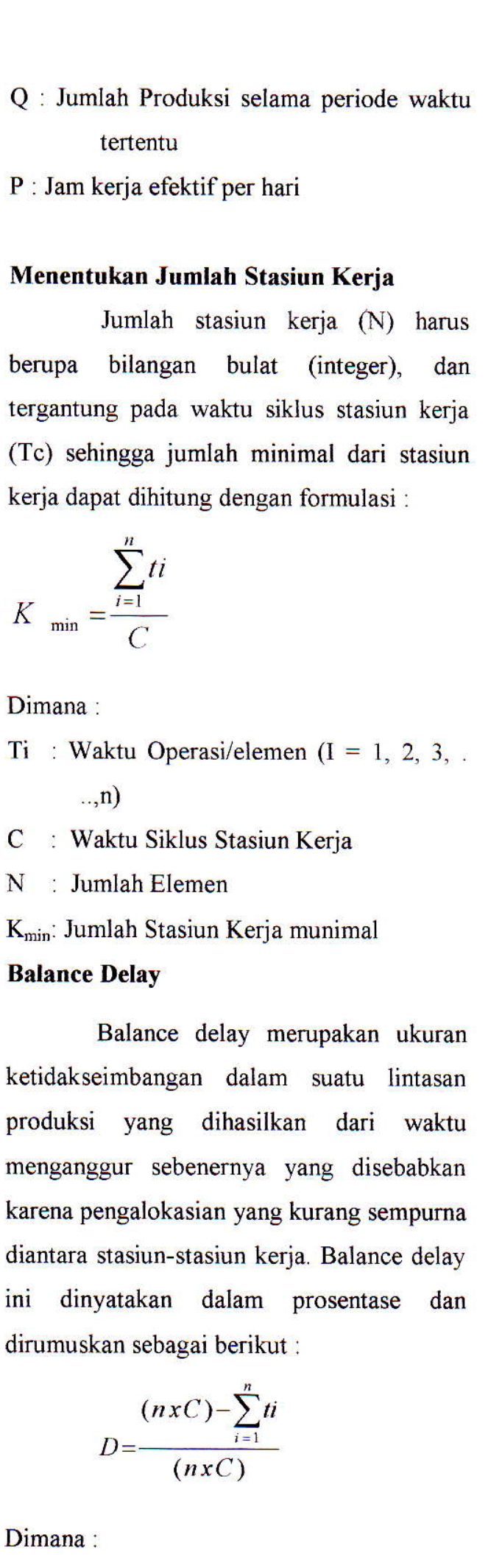

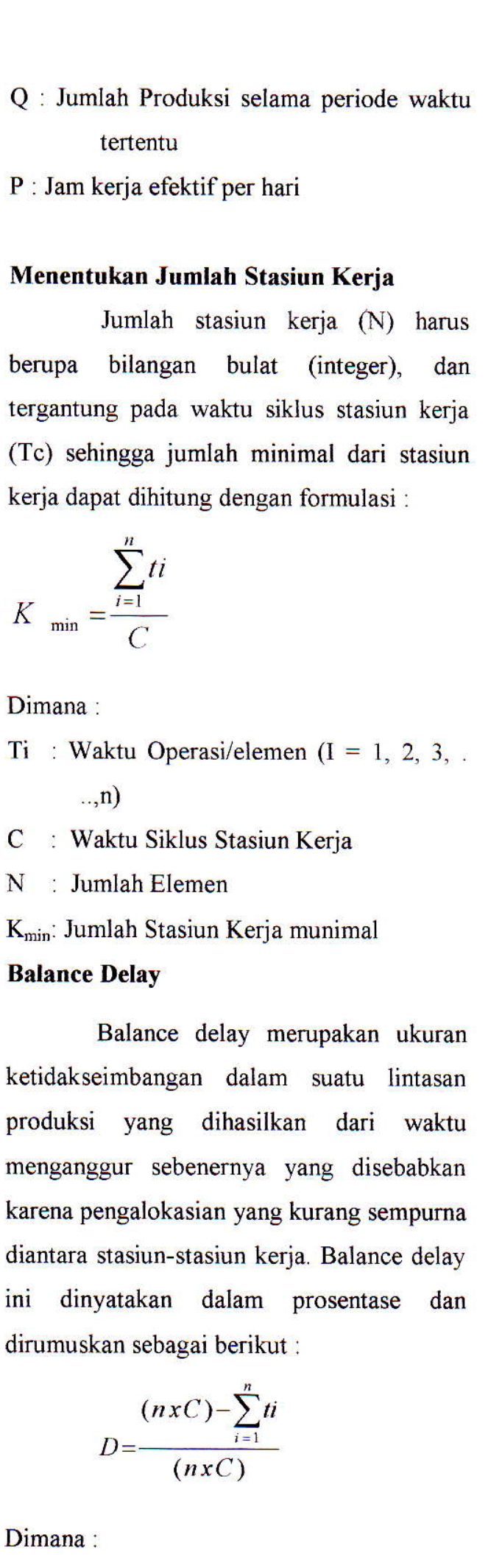

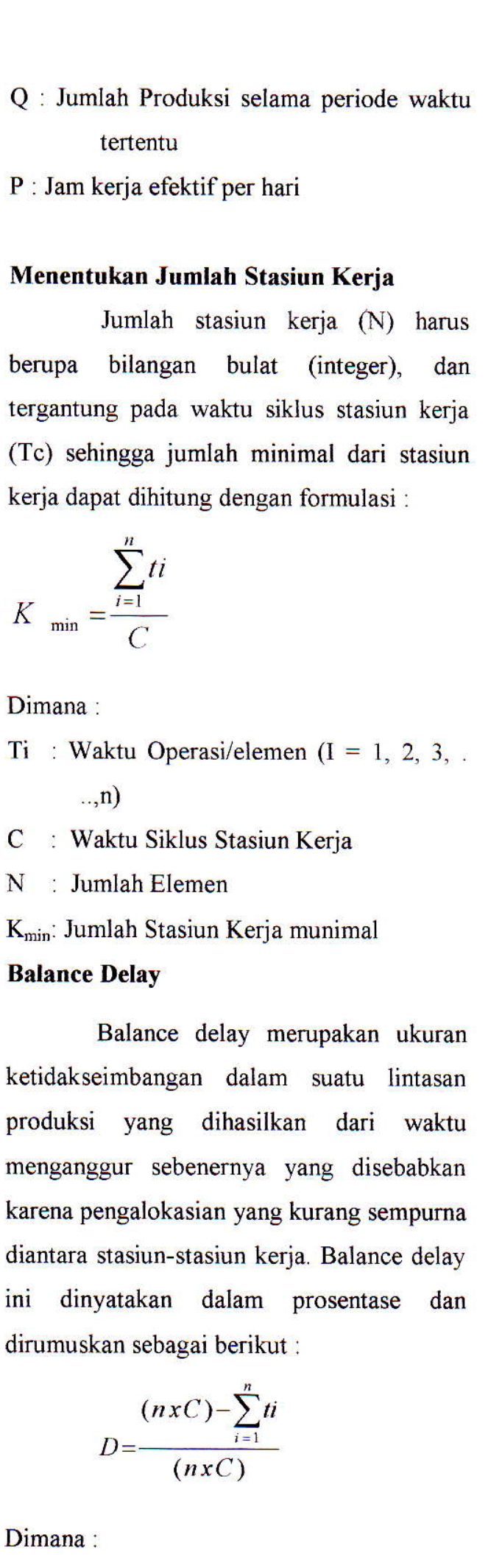

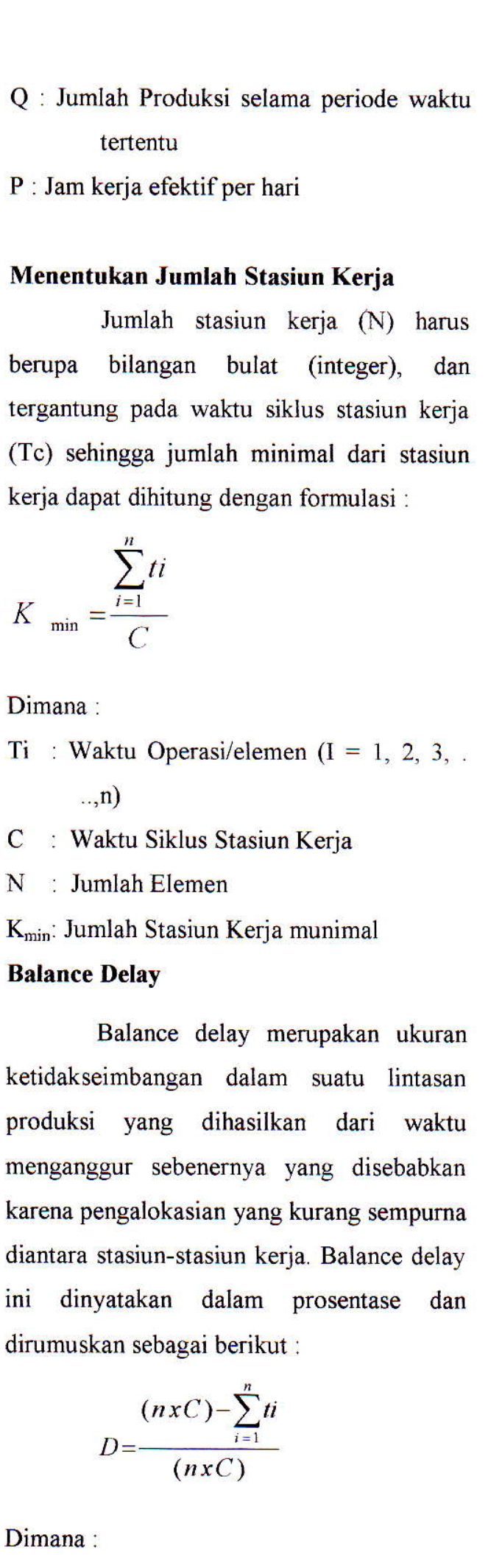

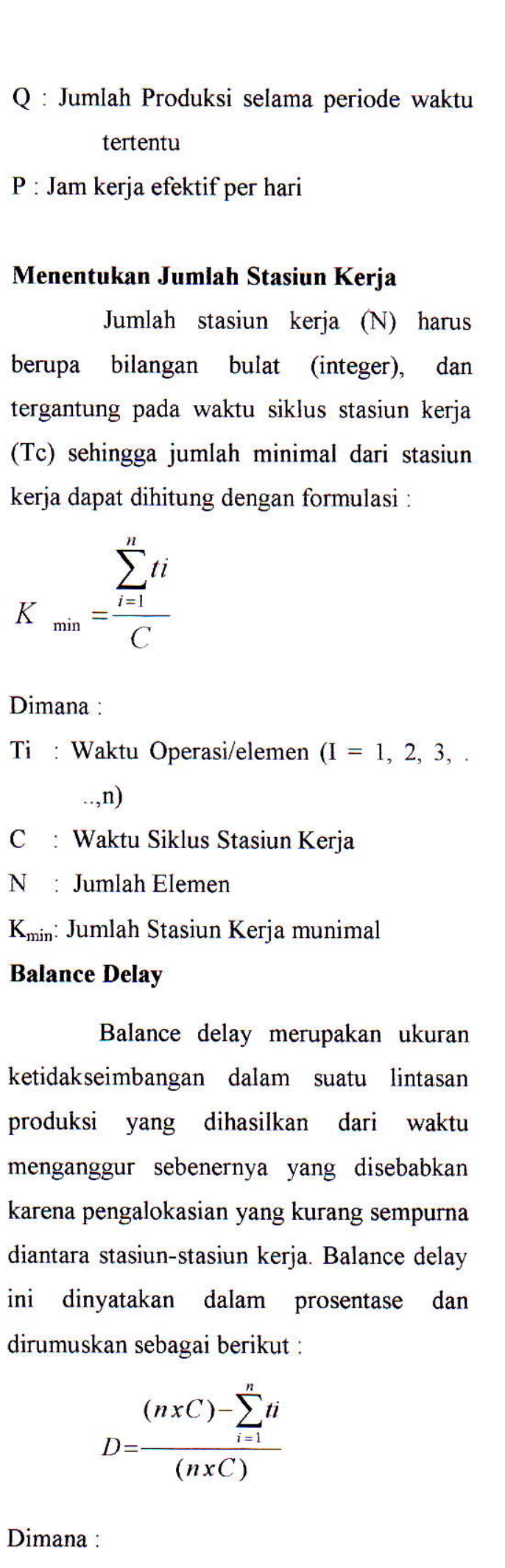

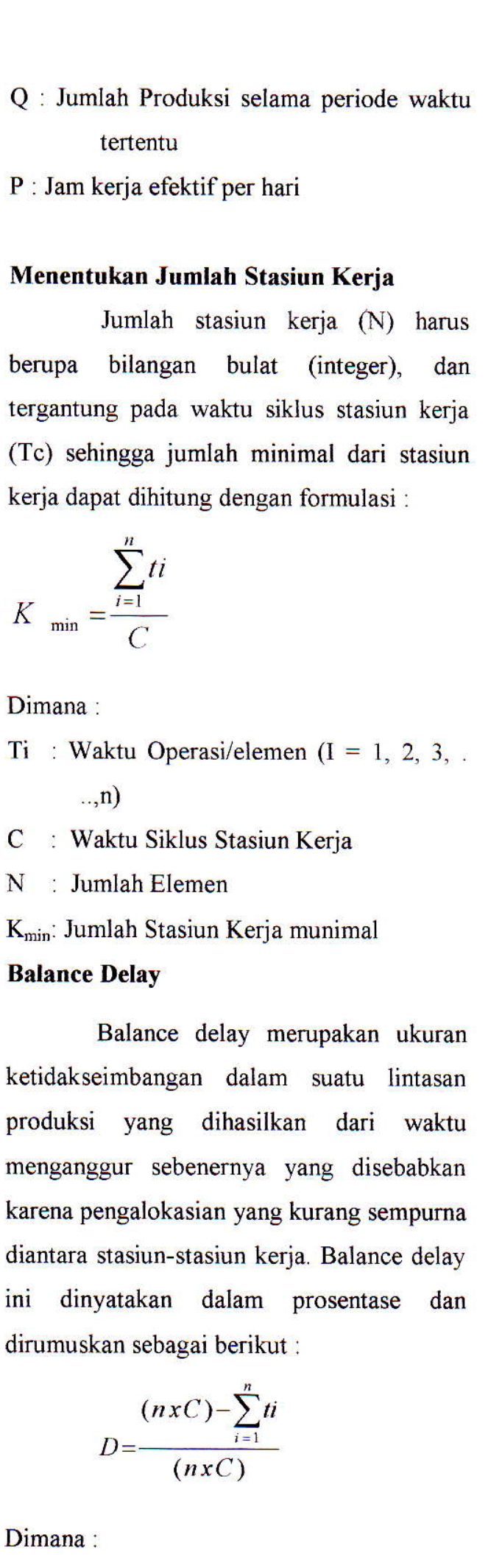

$$
D=\frac{(n x C)-\sum_{i=1}^{n} t i}{(n x C)}
$$

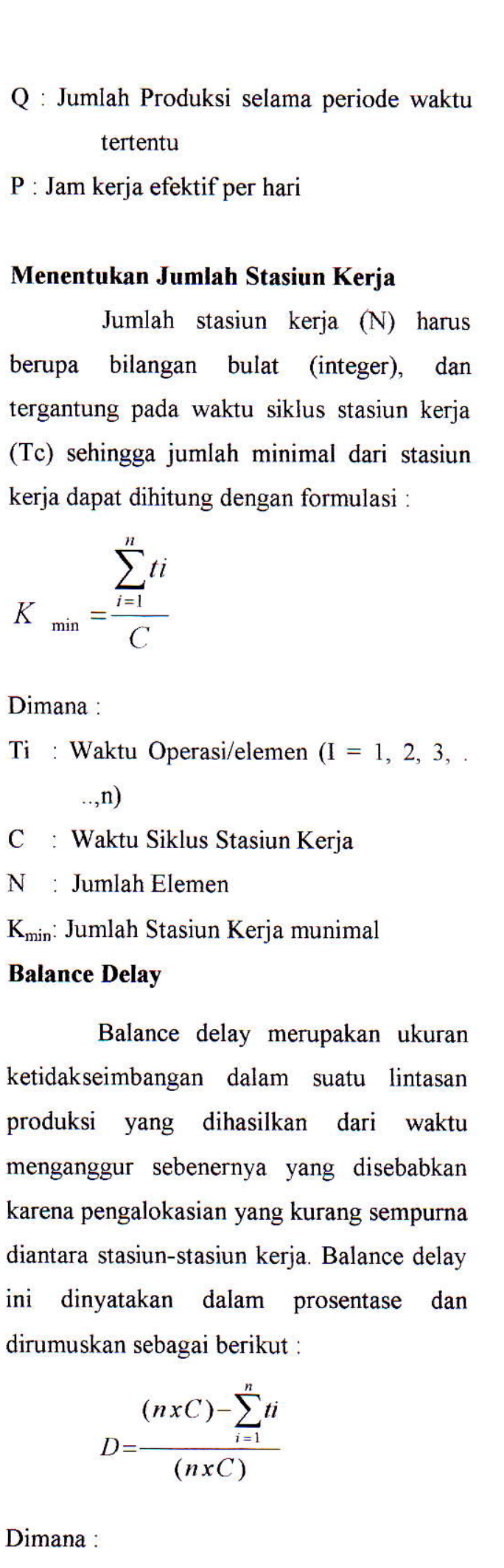

$\mathrm{N} \quad$ : Jumlah stasiun kerja

C : Waktu siklus terbesar dalam stasiun kerja 
$\sum t i$ : Jumlah waktu operasi dari semua

operasi

D : Balance delay (\%)

\section{Efisiensi Alokasi Stasiun Kerja}

Efisiensi setiap alokasi pada stasiun

kerja ini dinyatakan dalam bentuk prosentase, yang secara matematis dirumuskan sebagai berikut :

Effisiensi $=100 \%-\%$ Balance Delay

\section{Menghitung Output Produksi}

Untuk menghitung output produksi digunakan rumus :

$$
Q=\frac{P}{T_{c}}
$$

Dimana :

$\begin{array}{ll}P & \text { : Periode waktu efektif } \\ \text { Tc } & \text { : Waktu Siklus } \\ \text { Q } & \text { : Output produksi per periode } \\ \text { waktu } & \end{array}$

\section{METODOLOGI PENELITIAN}

\section{Data yang Diperlukan}

Untuk proses pengerjaan dengan metode rank positional wieght ini data-data yang diperlukan adalah :

1. Urutan proses produksi

2. Data waktu kerja (proses) untuk tiaptiap elemen kerja

3. Jam kerja efektif / hari

4. Nilai performance (kemampuan) rating dari operator
5. Waktu longgar (alowance) dari operator selama proses produksi berlangsung

\section{Tahap Pengolahan Data}

1. Tahap Pembuatan Precedence Diagram Berdasarkan waktu baku yang telah dihitung, akan dibuat precedance diagramnya, dan untuk mengetahui keoptimalan dari perancangan akan dilakukan trial and error dari jumlah stasiun kerjanya dan akan dihitung balance delay yang minimal dengan efisiensi yang optimal

2. Tahap Analisa Pembahasan

Dengan memasukkan beberapa jumlah stasiun kerja sebagai alternatif perancangan, selanjutnya akan dianalisa perbandingan antara balance delay, efisiensi lini produksi serta output produksi dari perancangan ini dengan kondisi awal yang terjadi di perusahaan.

\section{HASIL DAN PEMBAHASAN}

\section{Kondisi Awal Pengelompokan Stasiun Kerja}

Untuk saat ini Perusahaan belum menerapkan keseimbangan lintasan (line balancing) dalam proses perakitan mesin jahit tepe ARM dan BED.Untuk analisa kondisi awal dilakukan dengan pengelompokan elemen-elemen kerja ke dalam stasiun kerja awal, yang mana hal ini akan mendapatkan waktu siklus dari tiap stasiun kerja, dan waktu siklus terbesr akan 
dianggap sebagai waktu siklus dari stasiun kerja awal. Adapun pengelompokan stasiun kerja awal adalah sebagai berikut :

\section{Tabel 1}

Pengelompokan elemen kerja ARM 15

\begin{tabular}{|c|c|c|c|}
\hline $\begin{array}{l}\text { Stasiun } \\
\text { Kerja }\end{array}$ & $\begin{array}{c}\text { Kode } \\
\text { Operasi }\end{array}$ & $\begin{array}{l}\text { Waktu } \\
\text { Operasi } \\
\text { (detik) }\end{array}$ & $\begin{array}{c}\text { Idle } \\
\text { Time } \\
\text { (detik) }\end{array}$ \\
\hline I & $\begin{array}{l}O-1 \\
O-2\end{array}$ & $\begin{array}{l}129.43 \\
124.32 \\
\end{array}$ & \\
\hline \multicolumn{2}{|c|}{ Waktu Siklus } & 253.75 & 0 \\
\hline II & $\begin{array}{l}\mathrm{O}-3 \\
\mathrm{O}-4 \\
\end{array}$ & $\begin{array}{c}64.00 \\
104.66 \\
\end{array}$ & \\
\hline \multicolumn{2}{|c|}{ Waktu Siklus } & 168.66 & 85.09 \\
\hline III & $\begin{array}{l}O-5 \\
O-6\end{array}$ & $\begin{array}{l}95.35 \\
61.79 \\
\end{array}$ & \\
\hline \multicolumn{2}{|c|}{ Waktu Siklus } & 157.14 & 96.61 \\
\hline IV & $\mathrm{O}-7$ & 90.61 & \\
\hline \multicolumn{2}{|c|}{ Waktu Siklus } & 90.61 & 163.14 \\
\hline $\mathbf{V}$ & $\begin{array}{l}\mathrm{O}-8 \\
\mathrm{O}-9 \\
\end{array}$ & $\begin{array}{c}95.65 \\
110.72 \\
\end{array}$ & \\
\hline \multicolumn{2}{|c|}{ Waktu Siklus } & 206.37 & 47.38 \\
\hline VI & $\begin{array}{l}O-10 \\
O-11 \\
\end{array}$ & $\begin{array}{l}56.46 \\
67.81 \\
\end{array}$ & \\
\hline \multicolumn{2}{|c|}{ Waktu Siklus } & 124.27 & 129.48 \\
\hline VII & $\begin{array}{l}\mathrm{O}-12 \\
\mathrm{O}-13 \\
\mathrm{O}-14 \\
\end{array}$ & $\begin{array}{l}75.33 \\
72.06 \\
34.34 \\
\end{array}$ & \\
\hline \multicolumn{2}{|c|}{ Waktu Siklus } & 181.73 & 72.02 \\
\hline VIII & $\mathrm{O}-15$ & 119.32 & \\
\hline \multicolumn{2}{|c|}{ Waktu Siklus } & 119.32 & 134.43 \\
\hline IX & $\begin{array}{l}O-16 \\
O-17 \\
O-18 \\
O-19 \\
O-20\end{array}$ & $\begin{array}{c}34.67 \\
12.08 \\
11.63 \\
6.74 \\
13.83 \\
\end{array}$ & \\
\hline \multicolumn{2}{|c|}{ Waktu Suklus } & 78.95 & 174.8 \\
\hline
\end{tabular}

Tabel 2

Pengelompokan elemen kerja BED 15

\begin{tabular}{|c|c|c|c|}
\hline $\begin{array}{l}\text { Stasiun } \\
\text { Kerja }\end{array}$ & $\begin{array}{c}\text { Kode } \\
\text { Operasi }\end{array}$ & $\begin{array}{l}\text { Waktu } \\
\text { Operasi } \\
\text { (detik) }\end{array}$ & $\begin{array}{l}\text { Idle } \\
\text { Time } \\
\text { (detik) }\end{array}$ \\
\hline I & $\begin{array}{l}\mathrm{O}-1 \\
\mathrm{O}-2\end{array}$ & $\begin{array}{l}182.27 \\
189.56 \\
\end{array}$ & \\
\hline \multicolumn{2}{|c|}{ Waktu Siklus } & 371.83 & 0 \\
\hline II & $\begin{array}{c}O-3 \\
O-4 \\
O-5 \\
O-14\end{array}$ & $\begin{array}{c}68.07 \\
122.49 \\
20.83 \\
7.14\end{array}$ & \\
\hline \multicolumn{2}{|c|}{ Waktu Siklus } & 218.53 & 153.3 \\
\hline III & $\begin{array}{c}O-7 \\
O-8 \\
O-9 \\
O-13 \\
\end{array}$ & $\begin{array}{c}46.04 \\
91.14 \\
88.83 \\
0\end{array}$ & \\
\hline \multicolumn{2}{|c|}{ Waktu Siklus } & 226.01 & 145.82 \\
\hline IV & $\begin{array}{c}\mathrm{O}-6 \\
\mathrm{O}-11 \\
\mathrm{O}-12\end{array}$ & $\begin{array}{l}72.75 \\
60.01 \\
63.09\end{array}$ & \\
\hline \multicolumn{2}{|c|}{ Waktu Siklus } & 195.85 & 175.98 \\
\hline $\mathbf{V}$ & $\begin{array}{l}O-10 \\
O-15\end{array}$ & $\begin{array}{c}126.19 \\
25.71 \\
\end{array}$ & \\
\hline
\end{tabular}

\begin{tabular}{|c|c|c|c|}
\hline & $\mathrm{O}-16$ & 25.43 & \\
$\mathrm{O}-17$ & 23.51 & \\
\hline \multicolumn{2}{|c|}{ Waktu Siklus } & 200.84 & 170.99 \\
\hline
\end{tabular}

Test Keseragaman Data

Test keseragaman data ini dengan tujuan untuk mengetahui apakah ada data pengamatan yang ekstrim. Contoh perhitungan keseragaman data adalah sebagai berikut :

* Penentuan nilai rata-rata

$$
(\bar{X})=\frac{\sum X}{N}
$$

* Menentukan nilai standart deviasi

$S D=\sqrt{\frac{\left(X_{1}-\bar{X}\right)^{2}+\left(X_{2}-\bar{X}\right)^{2}+\ldots . .+\left(X_{n}-\bar{X}\right)^{2}}{n-1}}$

* Keseragaman Data

$$
\begin{aligned}
& B K A=(\bar{X})+k S D \\
& B K B=(\bar{X})-k S D
\end{aligned}
$$

\section{Test Kecukupan Data}

Test ini dilakukan untuk mengetahui apakah data yang kita ambil sudah mewakilai populasi yang ada, ini dapat diketahui dari nilai N'< N. Dimana :

$$
N^{\prime}=\left(\frac{k / s \sqrt{N\left(\sum X^{2}\right)-\left(\sum X\right)^{2}}}{\sum X}\right)^{2}
$$

Dalam hal ini digunakan tingkat kepercayaan 95\% dengan tingkat ketelitian $5 \%$. 


\section{Perhitungan waktu Standart untuk tiap-tiap Operasi}

Tabel 3

Waktu Standart untuk Tipe Arm 15

\begin{tabular}{|c|c|c|c|c|}
\hline No & $\begin{array}{c}\text { Kode } \\
\text { Operasi }\end{array}$ & $\begin{array}{c}\text { Waktu Normal } \\
\text { (Detik) }\end{array}$ & $\begin{array}{c}\text { Allowance } \\
(\%)\end{array}$ & $\begin{array}{c}\text { Waktu Baku } \\
\text { (Detik) }\end{array}$ \\
\hline 1 & $\mathrm{O}-1$ & 110.02 & 15 & 129.43 \\
\hline 2 & $\mathrm{O}-2$ & 105.68 & 15 & 124.32 \\
\hline 3 & $\mathrm{O}-3$ & 54.40 & 15 & 64.00 \\
\hline 4 & $\mathrm{O}-4$ & 88.96 & 15 & 104.66 \\
\hline 5 & $O-5$ & 81.05 & 15 & 95.35 \\
\hline 6 & $0-6$ & 52.52 & 15 & 61.79 \\
\hline 7 & $0-7$ & 77.02 & 15 & 90.61 \\
\hline 8 & $\mathrm{O}-8$ & 81.30 & 15 & 95.65 \\
\hline 9 & $0-9$ & 94.11 & 15 & 110.72 \\
\hline 10 & $\mathrm{O}-10$ & 47.99 & 15 & 56.46 \\
\hline 11 & $0-11$ & 57.66 & 15 & 67.84 \\
\hline 12 & $\mathrm{O}-12$ & 64.03 & 15 & 75.33 \\
\hline 13 & $\mathrm{O}-13$ & 61.25 & 15 & 72.06 \\
\hline 14 & $\mathrm{O}-14$ & 29.19 & 15 & 34.34 \\
\hline 15 & $0-15$ & 101.42 & 15 & 119.32 \\
\hline 16 & $O-16$ & 29.47 & 15 & 34.67 \\
\hline 17 & $\mathrm{O}-17$ & 10.27 & 15 & 12.08 \\
\hline 18 & O- 18 & 9.88 & 15 & 11.63 \\
\hline 19 & O- 19 & 5.73 & 15 & 6.74 \\
\hline 20 & $\mathrm{O}-20$ & 11.76 & 15 & 13.83 \\
\hline
\end{tabular}

Tabel 4

Waktu Standart untuk Tipe BED 15

\begin{tabular}{|c|c|c|c|c|}
\hline NO & $\begin{array}{c}\text { Kode } \\
\text { Operasi }\end{array}$ & $\begin{array}{c}\text { Waktu Normal } \\
\text { (Detik) }\end{array}$ & $\begin{array}{c}\text { Allowance } \\
(\%)\end{array}$ & $\begin{array}{c}\text { Waktu Baku } \\
\text { (Detik) }\end{array}$ \\
\hline 1 & $\mathrm{O}-1$ & 154.93 & 15 & 182.27 \\
\hline 2 & $\mathrm{O}-2$ & 161.12 & 15 & 189.56 \\
\hline 3 & $\mathrm{O}-3$ & 57.86 & 15 & 68.07 \\
\hline 4 & $\mathrm{O}-4$ & 104.12 & 15 & 122.49 \\
\hline 5 & O -5 & 17.70 & 15 & 20.83 \\
\hline 6 & $\mathrm{O}-6$ & 61.84 & 15 & 72.75 \\
\hline 7 & $\mathrm{O}-7$ & 39.13 & 15 & 46.04 \\
\hline 8 & $\mathrm{O}-8$ & 77.47 & 15 & 91.14 \\
\hline 9 & O -9 & 75.50 & 15 & 88.83 \\
\hline 10 & $\mathrm{O}-10$ & 107.26 & 15 & 126.19 \\
\hline 11 & $\mathrm{O}-\mathrm{II}$ & 51.01 & 15 & 60.01 \\
\hline 12 & $\mathrm{O}-12$ & 45.12 & 15 & 53.09 \\
\hline 13 & $\mathrm{O}-13$ & - & - & - \\
\hline 14 & $\mathrm{O}-14$ & 6.07 & 15 & 7.14 \\
\hline
\end{tabular}




\begin{tabular}{|l|l|l|l|l|}
\hline 15 & $O-15$ & 21.85 & 15 & 25.71 \\
\hline 16 & $\mathrm{O}-16$ & 21.61 & 15 & 25.43 \\
\hline 17 & $\mathrm{O}-17$ & 19.99 & 15 & 23.51 \\
\hline
\end{tabular}

\section{PERANCANGAN STASIUN KERJA DENGAN METODE RANK POSITIONAL WEIGHT}

Untuk perancangan line balancing disini digunakan metode rank positional weight dan digunakan bantuan program QS (Quantitative System).Adapunhasil dari perancangan ini nanti akan dibandingkan dengan kondisi awal yang ada / diterapkan di perusahaan ini. Adapun langkah-langkah itu adalah sebagai berikut :

\section{Penentuan Bobot Fungsi}

Penentuan bobot fungsi untuk suatu proses operasi dihitung dari jumlah waktu operasi itu sendiri serta waktu dari setiap operasi yang mengikutinya. Kemudian tiap operasi ini akan disusun berurutan berdasarkan bobot posisi dari yang terbesar sampai yang terkecil.

\section{Perancangan Stasiun Kerja baru}

Pengelompokan ekemen kerja kedalam stasiun-stasiun kerja ini dengan tujuan agar pembebanan kerja untuk tiap-tiap stasiun akan menjadi seimbang, hal ini dapat diketahui dengan adanya nilai balance delay yang minimal.Untuk proses perancangan ini akan digunakan program QS (Quantitative System) dengan jalan melakukan trial and error pada waktu siklusnya.

\section{Untuk produk tipe ARM 15}

Jika output produksi 113.50 unit / hari (kondisi saat ini), maka :

$T C=\frac{P}{Q}=\frac{8 \times 60 \times 60}{113.50}=253.75 \mathrm{det}$ ik/unit
Jika output produksi 114 unit / hari ,maka :

$T C=\frac{P}{Q}=\frac{8 \times 60 \times 60}{114}=252.63 \mathrm{det}$ ik $/$ unit

Jika demand produksi 116 unit / hari , maka :

$T C=\frac{P}{Q}=\frac{8 \times 60 \times 60}{116}=248.28 \mathrm{det}$ ik/unit

Jika demandproduksi 115.2 unit / hari , maka :

$T C=\frac{P}{Q}=\frac{8 \times 60 \times 60}{115.2}=250 \mathrm{det}$ ik/unit

Selanjutnya berdasarkan TC diatas akan dilakukan perancangan dengan bantuan software QS untuk mengetahui jumlah stasiun kerjanya, balance delay, dan efisiensinya. Hasil yang optimal adalah TC yang memiliki Balance delay yang minimal. Adapun rangkuman hasil dari pengolahan data dengan menggunakan QS (Quantitative System) adalah sebagai berikut :

Tabel 5

Perancangan Stasiun Kerja Tipe

ARM 15

Dengan Software QS

\begin{tabular}{|c|c|c|c|}
\hline $\begin{array}{c}\text { Cycle Time } \\
\text { (detil) }\end{array}$ & $\begin{array}{c}\text { Jumlah } \\
\text { Stasiun } \\
\text { kerja }\end{array}$ & $\begin{array}{c}\% \\
\text { Balance } \\
\text { Delay }\end{array}$ & Efisiensi \\
\hline 253.75 & 7 & 20.57255 & 79.4245 \\
\hline 252.63 & 7 & 21.91686 & 78.08314 \\
\hline 248.28 & 7 & 20.54881 & 79.45119 \\
\hline 250 & 7 & 21.09543 & 78.90457 \\
\hline
\end{tabular}

2. Untuk produk tipe BED 15

> Jika output produksi 77.45 unit / hari (kondisi saat ini), maka : 
TC $=\frac{P}{Q}=\frac{8 \times 60 \times 60}{77.45}=371.85 \mathrm{det}$ ik $/$ unit

Jika demand produksi 80 unit / hari, maka :

$T C=\frac{P}{Q}=\frac{8 \times 60 \times 60}{80}=360 \mathrm{det}$ ik/unit

Jika demand produksi 120 unit / hari, maka :

$T C=\frac{P}{Q}=\frac{8 \times 60 \times 60}{120}=240 \mathrm{det}$ ik $/$ unit

Berikutnya berdasarkan TC tersebut diatas akan dilakukan pengolahan dengan menggunakan software QS, seperti halnya yang dilakukan pada tipe produk yang pertama. Adapun rangkuman hasil dari pengolahan data dengan menggunakan QS (Quantitative System) adalah sebagai berikut

Tabel 6

Perancangan Stasiun Kerja Tipe BED 15 Dengan Software QS

\begin{tabular}{|c|c|c|c|}
\hline $\begin{array}{c}\text { Cycle } \\
\text { Time } \\
\text { (detik) }\end{array}$ & $\begin{array}{c}\text { Jumlah } \\
\text { Stasiun } \\
\text { kerja }\end{array}$ & $\begin{array}{c}\% \\
\text { Balance } \\
\text { Delay }\end{array}$ & $\begin{array}{c}\% \\
\text { Efisiensi }\end{array}$ \\
\hline 371.85 & 4 & 19.11658 & 80.88342 \\
\hline 360 & 5 & 33.16333 & 66.83667 \\
\hline 240 & 6 & 16.45417 & 83.54583 \\
\hline
\end{tabular}

\section{KESIMPULAN}

Setelah dilakukan pengolahan data dengan menggunakan Software QS (Quantitative System) dan analisa pembahasan maka dapat diambil kesimpulan sebagai berikut :

1. Lintasan keseimbangan yang paling optimal untuk Tipe Produk ARM 15 adalah dengan kreteria sebagai berikut :

* Waktu Siklus

248.3 Detik

Jumlah Stasiun Kerja

7 Stasiun
* \% Balance Delay

21.54881

* \% Efisiensi

78.45119

* Output Produksi / Hari

116 Unit

2. Lintasan keseimbangan yang paling optimal untuk Tipe Produk BED 15 adalah dengan kreteria sebagai berikut :

* Waktu Siklus

240 Detik

* Jumlah Stasiun Kerja

6 Stasiun

* \% Balance Delay

16.45417

* \% Efisiensi

83.5483

* Output Produksi / Hari

120 Unit

3. Dengan kondisi optimal seperti pada poin 1 dan 2, maka terjadi peningkatan output produksi untuk tiap0tiap tipe produk sebagai berikut :

* Untuk ARM 15 peningkatan output produksi sebesar 2.5 unit / hari dengan peningkatan efisiensi sebesar $17.95119 \%$

* Untuk BED 15 peningkatan output produksi sebesar 42.56 unit / hari dengan peningkatan efisiensi sebesar $18.8383 \%$

\section{DAFTAR PUSTAKA}

Chase, Richard B and Aquilano, 1995, Production and Operation Management : Manufacturing and Service, Irwin, Chicago.

Elsyayed, 1985, Analysis and Control of Production System, Prentice Hall Inc, New York. 
Hill, Mc. Graw. ,1994, Industrial Enggeneering and Management, New York.

Matinich, Joseph S, , 1997, Production and Operation Management; An Applied Modern Approach, New York.

Mundel, Marvin E. Motion and Time
Sutalaksana, Anggawisastra, Teknik Tata Cara Kerja, Departemen Teknik Industri ITB Bandung

Wignjosoebroto, Sritomo, Ergonomi Studi Gerak dan Waktu, Guna Widya, 1995

Study Fifth Edition, New York 